2008

\title{
From Exclusion to Containment: Arendt, Sovereign Power, and Statelessness
}

Hayden

Follow this and additional works at: https://scholarlycommons.law.case.edu/swb

Part of the Human Rights Law Commons, and the Social and Behavioral Sciences Commons

\section{Recommended Citation}

Hayden. 2009. "From Exclusion to Containment: Arendt, Sovereign Power, and Statelessness." Societies Without Borders 3 (2): 248-269.

Available at: https://scholarlycommons.law.case.edu/swb/vol3/iss2/3 


\title{
From Exclusion to Containment: Arendt, Sovereign Power, and Statelessness
}

\author{
Patrick Hayden \\ University of St Andrews, Scotland, UK
}

Received 20 December 2007; accepted 2 February 2008

\begin{abstract}
Taking up Hannah Arendt's analysis of statelessness and her critique of sovereign power, this paper argues that the condition of 'rightlessness' has become normalized within the international order. In contrast to claims that globalization has undermined sovereignty, Arendt's work helps to illuminate how states continue to reinforce their power to exclude and contain stateless persons while simultaneously deploying the discourse of universal human rights. Current state policies reveal that rightlessness is deeply embedded within the logic of the inter-state system. In a globalizing world where states are increasingly called upon to conform to universal standards of human rights, millions of stateless persons continue to be segregated from the public realm of effective political agency by statist practices of global apartheid, thereby rendering them 'superfluous' human beings.
\end{abstract}

\section{Keywords}

Hannah Arendt, global apartheid, human rights, sovereignty, statelessness

\section{Introduction}

The United Nations High Commissioner for Refugees (UNHCR) estimates that at the end of 2006 there were 9.9 million refugees, 5.8 million stateless persons, 12.8 million internally displaced persons (IDPs), and 4.4 million asylum-seekers and other 'persons of concern', producing a total of 32.9 million displaced persons globally. ${ }^{1}$ These figures are conservative, however, because they include only those persons of concern specifically receiving protection and assistance from the UNHCR. Other stateless peoples, for instance, include the 4.3 million Palestinian refugees dispersed across

\footnotetext{
1) UNHCR 2007.
} 
the Middle East who fall under the mandate of the United Nations Relief and Works Agency instead of the UNHCR. Thus the actual numbers of displaced persons globally are likely to be considerably higher. Recent research suggests that there are at least 11 million stateless persons around the world. ${ }^{2}$ While stateless persons can be found not only in the 'anonymous' flows of refugees and IDPs, as well as in 'recognizable' groups such as the Roma, Kurds, and Biharis, unlike refugees they do not have legal or effective citizenship in relation to any state. Without legal or effective citizenship, stateless persons in essence have no rights. According to the UNHCR the deprivation of rights that accompanies statelessness often leaves stateless persons "in a Kafkaesque legal vacuum” which reduces them to "non-persons, legal ghosts." 3 What the UNHCR does not address, however, is the underlying structural condition that continually produces widespread statelessness.

Hannah Arendt lived the perilous and uncertain existence of a stateless person for eighteen years, from the time she fled Germany without travel documents in 1933 to when she became a naturalized US citizen in $1951 .{ }^{4}$ Arendt's experience led her to reflect critically upon both the fate of stateless persons during the mid-twentieth century and the larger question of the relationship between statelessness and the modern nation-state. The special significance of statelessness for Arendt is that it is symptomatic of "underlying structures which have today come into the open" through the appearance of transnational political catastrophes. ${ }^{5}$ More specifically, the phenomenon of mass statelessness starkly reveals "what had been hidden throughout the history of national sovereignty," 6 namely, the destructive contradiction between universal human rights and the sovereign power of the modern state. Contemporary history shows that the construction of the international system upon the sovereign power to exclude leads to the formation of "superfluous" human beings "that are put in concentration camps by their foes and in internment camps by their friends."

This article explores Arendt's critique of sovereignty and her account of the structural contradiction between sovereign power and universal human

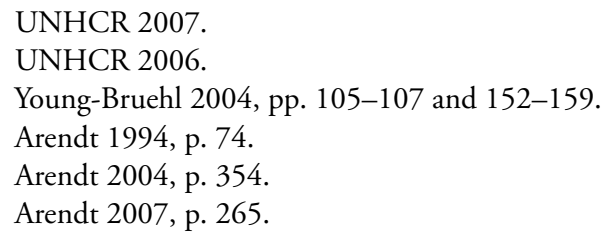


rights, and suggests that the arguments put forth by Arendt are quite useful in attempting to understand and theorize the continuing legal and political exclusion of the stateless. The most important aspect of Arendt's critique, I contend, is that it highlights how statelessness is not an aberrant or accidental phenomenon occurring despite the best efforts of states to prevent it, but a 'normalized' systemic condition produced by an international order predicated upon the power to exclude as the essence of statist politics. The political realities of statelessness experienced by Arendt and millions of other persons have not disappeared but have become the order of the day. Hence, Arendt's insights should lead us to interrogate the adequacy of recent claims that state power to exclude is being undermined by processes of globalization.

In the following two sections, I discuss Arendt's critical analysis of the modern conception of human rights and her concomitant critique of state sovereignty. For Arendt, the inherent contradiction between rights and sovereignty is manifested in the tragedy of statelessness and what she referred to as the condition of 'rightlessness' experienced by stateless persons. I then deploy her critique of sovereignty in order to call attention to the relationship between 'inclusive exclusion' and the efforts of powerful states to globally integrate a strategy of containment of stateless persons and refugees. I ultimately argue that this strategy reinforces a coercive system of global apartheid.

\section{The Sovereign Eclipse of Universal Human Rights}

Arendt offers a powerful critique of the modern conception of human rights which repudiates naturalist metaphysics and liberal subjectivism as the bases for human rights, arguing that the failure of such foundations was most clearly exemplified by the problem of stateless persons in the twentieth century. ${ }^{8}$ Even more significantly, this critique exposes the fact that the international order systematically generates statelessness as a consequence of several contradictions at the core of its normative and organizational principles. She observed that the international system has normalized the condition of displacement and political exclusion, ensuring that millions of innocent people are consigned daily to the oblivion of rightlessness. Arendt highlights the abject status of those who have ceased to belong

8) Arendt 2004, p. 353. 
to any state thus: "No paradox of contemporary politics is filled with more poignant irony than the discrepancy between the efforts of well-meaning idealists who stubbornly insist on regarding as 'inalienable' those human rights, which are enjoyed only by citizens of the most prosperous and civilized countries, and the situation of the rightless themselves."

Despite positing the autonomous sovereign subject as the foundation of universal rights, human rights were in fact first realized only in the particular contexts of the two national struggles of the American and French revolutions. The contradiction here is that the sovereignty of each autonomous individual had to be reconciled with that of all others in forming the body politic. ${ }^{10}$ What this meant was an essential devaluation of the importance of the supposedly inalienable rights of the individual vis-à-vis the national will and the collective right to self-determination. It follows that the rights set forth as resting solely upon the human being's natural life in reality presupposed not only the existence of a polity but also the sovereignty of the general will of the people. As Arendt effectively shows, this awkward coupling of individual sovereignty as the expression of subjective inalienable rights, and national sovereignty as the expression of the collective rights of the people to self-government underwrites the emergence of the modern nation-state. This implies that "man had hardly appeared as a completely emancipated, completely isolated being who carried his dignity within himself without reference to some larger encompassing order, when he disappeared again into a member of a people."11 The idealization of human rights based upon the metaphysical notion of a sovereign subject elevated the abstract individual above the nation-state, while simultaneously the affirmation of national sovereignty idealized as the "nebulous representative of a 'national soul' " meant that "human rights were protected and enforced only as national rights." 12

The contradiction between human rights and national sovereignty had further implications for the legitimacy of the state. The ascendancy of nationalism transformed the state from an entity whose "supreme function" was protection of the human rights of "all inhabitants in its territory no matter what their nationality," into one whose function was to distinguish between nationals and non-nationals and on this basis to "grant full

\footnotetext{
9) Arendt 2004, p. 355.

10) Arendt 2004, pp. 77-79.

11) Arendt 2004, p. 369.

12) Arendt 2004, p. 297.
} 
civil and political rights only to those who belonged to the national community by right of origin and fact of birth." ${ }^{13}$ The state, in other words, was transformed from an impartial instrument of the law committed to the equal protection of each individual's rights, into an ideological instrument of the "pseudomystical" nation whose "will" and interests were committed to protecting only the members of this nation. ${ }^{14} \mathrm{With}$ the ascendancy of nationalist sentiment over the rule of law - what Arendt refers to as the "conquest of the state by the nation" - the abstract "national interest" became prioritized over the interests of singular and concrete human beings. ${ }^{15}$ From this point the "tragedy of the nation-state," and by extension of the international system of states, was embodied in the fact that the legal protection of rights extended only to those persons recognized as "nationals."16 All non-nationals within a given territory were immediately subject to the potential for exclusion from the polity and its guarantee of equal rights. The 'decline' of the state thus signifies that its legal institutions no longer functioned equally for all its inhabitants, leaving nonnationals not simply on the margins of society but outside the law itself as 'threats' to the national interest.

The association of human rights with nationality meant in practice that these rights existed solely within domestic law and belonged only to recognized citizens of particular nation-states. The identification of citizenship with nationality rather than humanity became the precondition for the effective possession of human rights and coincided with the emphasis on mutually exclusive citizenries within the nation-state system. Thus, human rights were strictly delimited to the domain of a specific state and placed under the protection of a single government. This situation divested the Rights of Man of their supposedly universal and inalienable character, exposing them as entirely contingent and social. In the new statist era only membership within a particular nation-state could guarantee rights their legal status. However, those persons excluded from having a recognized place within a polity were compelled to live either as "exceptions" to the general equality assured to citizens (defined as nationals) or, what became increasingly the norm, "under conditions of absolute lawlessness." ${ }^{17}$ The

13) Arendt 2004, p. 296.

14) Arendt 2004, p. 297.

15) Arendt 2004, p. 296.

16) Arendt 2004, p. 379.

17) Arendt 2004, p. 343. 
paradoxical implication of this identification between human rights and nationality is that expulsion from a state results in the loss of legal and political status and therefore all human rights. "The Rights of Man," Arendt underscores, "had been defined as 'inalienable' because they were supposed to be independent of all governments; but it turned out that the moment human beings lacked their own government and had to fall back upon their minimum rights, no authority was left to protect them and no institution was willing to guarantee them." 18

Arendt's critical analysis of the philosophical underpinnings of the modern conception of rights thus identifies two fundamental contradictions at the heart of this doctrine. The first is that the interests of the pre-political sovereign subject as the bearer of individual rights conflict with the interests of the political sovereign state as the bearer of collective rights. The second is that as citizenship entitlements within the context of a particular state human rights are conditional and exclusive, premised upon nationality rather than humanity. This critique not only exposes the conflict between universalist ideals and particularist realities that erode the integrity of the conventional formulation of human rights, but more importantly it makes clear that within an international system predicated upon the supremacy of national sovereignty, human rights cannot be enforced outside the state. Arendt draws two further insights from her analysis: first, states have been empowered historically with the sovereign right to determine who is entitled to nationality and thus to possession of human rights, and second, that any person not accorded full citizenship status is excluded, to some degree, from human rights. The central paradox of the notion of inalienable human rights is that while the protection of human rights within the international system is inseparably tied to state sovereignty, states are also authorized to deprive citizens of those same rights and to exclude individuals from the condition of nationality that would enable them to have human rights. By controlling admission into or expulsion from nationality or citizenship, states thereby control each individual's prospects for the effective possession and exercise of human rights. ${ }^{19}$

\footnotetext{
18) Arendt 2004, p. 370.

19) Following customary practice of international law, the terms 'citizenship' and 'nationality' will be used synonymously.
} 


\section{Statelessness, Rightlessness, and the Power to Exclude}

The full implications of the sovereign power to exclude persons from political community became apparent when European governments began to denationalize large segments of their populations in the wake of World War I, leading to the creation of entire groups of people for whom "there was no country on earth in which they enjoyed the right to residence." 20 Arendt cites several examples of "mass denationalizations" during this period, such as the Belgian laws of 1922 and 1934 that "canceled naturalization of persons who had committed antinational acts during the war," the Italian (1926), Egyptian (1926), French (1927), and Turkish (1928) laws that allowed for the denaturalization of persons "who were a threat to the social order" or "who committed acts contrary to the interests" of the state, and the Austrian and German laws of 1933 that allowed the state to denationalize any citizen living abroad. ${ }^{21}$ Although denationalization became a favoured weapon of totalitarian states, this particular prerogative of "full sovereign power" in principle can be wielded by any type of state; further, the mass denationalizations of the 1920s and 1930s established an "easy precedent" for the postwar period..$^{22}$ Indeed, at the time of writing The Origins of Totalitarianism, Arendt was deeply disturbed by proposals in the United States to strip US-born nationals who were communists (or suspected of being so) of their citizenship. What made these measures so "sinister" is that they could be proposed "in all innocence," as expressions of the sacrosanct sovereign right to protect national interests. ${ }^{23}$

The forced deportations of unwanted minority groups and the mass denationalizations of "undesirable" populations led to the emergence of the apatride as a figure symptomatic of "a world organized into nationstates": the stateless person lacking governmental representation and protection and thus forced to live outside the pale of the law. ${ }^{24}$ The explosion in stateless and refugee numbers in the mid-twentieth century quickly exposed the structural deficiencies of the international system, in particular the "inability of European nation-states to guarantee human rights to those who had lost nationally guaranteed rights." ${ }^{25}$ From this point on

20) Arendt 2004, p. 352.

21) Arendt 2004, p. 355.

22) Arendt 2004, p. 354 and p. 353.

23) Arendt 2004, p. 356.

24) Arendt 2004, p. 354.

25) Arendt 2004, p. 343. 
mass statelessness, which was and continues to be treated discursively and practically as an exceptional or temporary problem, in fact became a permanent phenomenon constituted by the sovereign rights of expulsion and denationalization. This had several further negative effects upon the nationstate system and the doctrine of human rights. First, the right of asylum, associated with the longstanding practice of providing refuge, protection and sanctuary to exiles and the persecuted since ancient times, collapsed because it was considered anachronistic and "in conflict with the international rights of the state." 26

Second, the two 'remedies' of repatriation and naturalization were inefficacious in the face of statelessness as a mass phenomenon. Naturalization was both restrictively offered to small numbers of individuals and persistently susceptible to revocation by states, while repatriation proved equally problematic in that neither the country of origin (which typically caused the problem to begin with by expelling the person who thereby became stateless) nor any other state would accept stateless persons. ${ }^{27}$ In essence, stateless persons were consigned to zones of lawlessness subsisting within and between the juridical territories of sovereign states. This situation led to the creation of novel sites designed specifically to accommodate the increasing numbers of stateless persons and refugees globally: the internment camp. The internment camp, writes Arendt, "has become the routine solution for the problem of domicile" and "the only practical substitute for a nonexistent homeland" which the world has "to offer the stateless." ${ }^{28}$

It is important to note that Arendt's analysis of statelessness goes beyond the narrow juridical definition that distinguishes between the stateless person and the refugee. Instead, Arendt insists on the need to recognize both the de jure stateless, or "a person who is not considered as a national by any State under the operation of its law," ${ }^{29}$ and the de facto stateless, such as refugees, internally displaced persons, resident aliens and immigrants threatened by denationalization, ineffective nationality, or who are unable to prove either their nationality or that they are legally stateless. ${ }^{30}$ Arendt stresses the qualitative condition of statelessness as extending beyond the merely factual deprivation of national legal status and as occurring irrespective of territorial

\footnotetext{
26) Arendt 2004, p. 357.

27) Arendt 2004, pp. 357-361.

28) Arendt 2004, p. 355 and p. 361.

29) 1954 Convention Relating to the Status of Stateless Persons, article 1.

30) Arendt 2004, p. 356; see Batchelor 1995, pp. 91-92.
} 
boundaries. Indeed, the stateless are distinguished precisely by the fact that they have "been ejected from the old trinity of state-people-territory." ${ }^{31}$ For this reason, Arendt claims that "the core of statelessness" - namely, the deprivation of one's legal status and thus loss of the ability to exercise rights effectively within a political community - is "identical with the refugee question" insofar as refugees are, for all practical purposes, unable to enjoy the rights and protections afforded by citizenship. ${ }^{32}$

It is at this point that the philosophical and political dimensions of Arendt's critique of the traditional doctrine of human rights converge, and provides the basis for her claim that the only fundamental human right is the right to have rights. For Arendt, it is clear that the loss of membership in a political community - the loss of nationality or citizenship - is equivalent to the loss of all human rights and dignity: it is the condition of complete rightlessness suffered by the abstract human being. ${ }^{33}$ This is because nationality has become the defining qualification for the individual exercise and the state protection of rights under international law. To be "merely human" means that a person is excluded not simply from any particular state but from all states; such persons "no longer belong to any community whatsoever" and therefore are thrust "out of legality altogether." ${ }^{34}$ It is for this reason that Arendt insists that the most basic right of each individual, prior to any of the specific human rights proclaimed in various declarations, is the right to have rights, that is, the right to be legally and politically included in a community that guarantees the equal status of all persons residing there, citizens and non-citizens alike, regardless of nationality. ${ }^{35}$

Deprived of their rights, the stateless are "forced to live outside the common world" and thus are "thrown back... on their natural givenness." 36 This condition reduces the stateless to the status of physical object and is a sign of the loss of human dignity. Specifically, to suffer a total deprivation of rights means losing the political agency and legal recognition by which one rises above the "the abstract nakedness of being human and nothing but human" to become a person (persona), an agent in the public realm where one's actions are acknowledged and valued by others. ${ }^{37}$ It is because

31) Arendt 2004, p. 358.

32) Arendt 2004, p. 357.

33) See Isaac 1998.

34) Arendt 2004, p. 375 and p. 373.

35) Arendt 2004, p. 377.

36) Arendt 2004, p. 383.

37) Arendt 2004, p. 377. 
the stateless are isolated and expelled from political communities that they are no longer able to claim human rights. The further point to take from Arendt's analysis of human rights is that while the loss of one's place in the world is what activates rightlessness, what makes rightlessness such an acute political harm is the virtual "impossibility of finding a new one." 38 Those persons who remain unclaimed by any community can then be considered "perfectly superfluous," their lives constantly endangered by the power of states to effectuate the condition of rightlessness. ${ }^{39}$

Because we "have really started to live in One World," 40 in which there is seemingly no escape from the globalized system of sovereign states, the continued insistence that state sovereignty entails an unimpeachable right of exclusion is a sure recipe for mass human tragedy. Stateless persons are not simply found "outside" society but instead are a by-product of the society of states, an "inevitable residue" of the nation-state system which relentlessly produces superfluous human beings. ${ }^{41}$

\section{Exclusion and Containment: A Dual Strategy}

Efforts have been made to address the problems identified by Arendt, but because these efforts remain configured by the imperatives of sovereign power success in this direction has been limited at best. ${ }^{42}$ The inability of the human rights regime to 'solve' the burgeoning problem of stateless persons underscores Arendt's point that statelessness is not fundamentally a problem of geographical space but of political space. ${ }^{43}$ The obvious remedial

\footnotetext{
38) Arendt 2004, p. 372.

39) Arendt 2004, p. 375.

40) Arendt 2004, p. 377.

41) Arendt 2004, p. 247.

42) While the 1948 Universal Declaration of Human Rights, for example, asserts that everyone has a right to nationality (Article 15 and a right to seek asylum in other countries (Article 14), these rights are formulated in such a way as to reinforce the notion that nationality is a prerequisite to holding human rights and thus that those without effective or legal nationality are necessarily rightless. Further, Article 1 of the 1954 Convention Relating to the Status if Stateless Persons provides only a legal definition of a stateless person as "a person who is not considered as a national by any State under the operation of its law." Thus the Convention's definition defines only the condition of de jure statelessness, apparently because the drafters of the Convention mistakenly believed that all de facto stateless persons were refugees (see Batchelor 1995, p. 92).

43) Nyers 2006, p. 17; see also Benhabib 2002.
} 
solution to statelessness is for states to grant nationality to all stateless persons, yet the power to grant nationality remains a sovereign prerogative immune to human rights ideals.

Here the demarcations between who is and who is not included within the public space of a community are not territorial per se, but rather ideologically, racially, economically, and politically determined. Consequently the phenomenon of statelessness is hardly accidental or aberrant. There are many ways in which forced displacement, dislocation, immigration, and other varieties of global border-crossing intersect, and numerous historical trends in how stateless persons, asylum-seekers, and immigrants have been treated. A comprehensive analysis of these trends and modalities is beyond the aim of this paper. What I want to highlight instead is a single recent trend in the treatment of stateless persons and refugees that arguably signals the ascension rather than decline of the sovereign power of exclusion exposed by Arendt. This trend is, in the words of Jacob Stevens, a global "strategy of containment." 44

The strategy of containment has been devised and enforced through numerous national and international mechanisms since the 1970s, when Western states began to conceive of the work of the UNHCR above all in terms of "intervention in crisis zones of the Third World" rather than "resettlement" of European refugees. These "new" refugees were regarded as "problem people," a collective source of anxiety and potential instability due to their "irregularity." 45 The response has consisted not only of tightening border controls and immigration policies but of rationalizing the function of the UNHCR and other refugee organizations as 'emergency' or crisis relief.

Thus rather than focusing on granting asylum to refugees and stateless persons, and integrating them legally into communities that will enable them to assert their rights, the new strategic turn is towards containment and mass repatriation without the restoration of rights. This approach is achieved primarily by means of vast networks of internment camps, 'safe havens,' emergency centres, holding stations, and detention facilities. ${ }^{46}$ In these spaces of what Arendt termed 'superfluousness,' undesirables who have been deemed to belong nowhere are condemned to inclusive exclusion. ${ }^{47}$ Dispossessed of their human rights and political agency, the

\footnotetext{
44) Stevens 2006, p. 65.

45) Marfleet 2006, pp. 150-151.

46) Stevens 2006, pp. 65-67; Marfleet 2006, p. 151.

47) See Agamben 1998, pp. 28-29.
} 
stateless are simultaneously integrated within the decision-making authority of sovereign power and segregated from the normalized territory of potential host states.

These spaces of superfluousness are extraterritorial in that they may be situated either within or without the territorial borders of a sovereign state, yet in either case they are exempted from the jurisdiction of the 'normal' order of law. Perhaps the most well-known recent example of such a space is the camp at Guantánamo Bay established by the US government as a centrepiece of its 'War on Terror.' Yet more far-reaching examples of the strategy of containment abound. The Australian government's two-track policy of preventive interception and detention is notable here. This policy was crafted in the aftermath of the Tampa 'crisis', in which more than 400 Afghan refugees in a sinking fishing boat were rescued by a Norwegian cargo ship that then attempted to offload them at Christmas Island. After the Tampa was denied permission to enter Australia's territorial waters, Special Forces boarded the ship and the refugees were transported by warship to the island of Nauru, where the Australian government has established an offshore detention centre in which to hold and process asylum-seekers away from the territory of the Australian state. ${ }^{48}$

Following this incident the Australian government formally inaugurated the so-called 'Pacific Solution.' This policy is designed to intercept and prevent boats carrying asylum-seekers from entering Australian territorial waters, and divert asylum-seekers to detention camps established on several South Pacific island nations. ${ }^{49}$ One of the first components of this new policy was passage of the Migration Amendment (Excision from Migration Zone) Act. ${ }^{50}$ This act excised a number of external territories (including Christmas Island) from Australia's migration zone, which means that asylum-seekers ('unauthorized arrivals') arriving in these territories now have no right to apply for a visa, have no recourse to Australian courts, and may be transported to offshore detention facilities. A cornerstone of the 'Pacific Solution' is the policy of mandatory detention. According to this policy all 'unauthorized arrivals' on Australian territory are compulsorily imprisoned within one of the detention facilities established throughout Australia and the Pacific islands. Asylum-seekers may be detained indefinitely, the facilities are exempted from judicial review and children,

\footnotetext{
48) Howard 2003.

49) Oxfam Australia 2002.

50) Available online at http://www.aph.gov.au/library/pubs/bd/2001-02/02bd069.htm.
} 
including infants, are detained though often separated from close family members.

The Australian government also introduced a new type of visa, the 'Temporary Protection Visa' (TPV), to replace the Permanent Protection Visa (PPV) previously given to asylum-seekers, on the grounds that the PPVs "were far more generous than required by Australias international obligations." TPVs allow visa holders to remain in Australia for up to three years; during this period they may be deported at any time by the Australian government and when the visa expires they must reapply for a further TPV, which again provides the government with the opportunity to revoke their refugee status and deport them if they "are no longer in need of Australia's protection." In August 2003, the TPV policy was made retroactive to supersede all PPVs granted prior to that date. ${ }^{51}$ 'Temporary protection' is now the only status granted to all refugees in Australia, including those who have already been through a full asylum determination in light of the 1951 Refugee Convention. ${ }^{52}$

Several recent decisions by the High Court of Australia further strengthen the sovereign power of containment and exclusion. In Behrooz v Secretary, Department of Immigration and Multicultural and Indigenous Affairs (August 2004), the High Court held that the conditions of immigration detention are irrelevant to the question of whether the detention is lawful, and thus that even inhumane conditions of detention cannot excuse escape from administrative detention centres. In Al-Kateb $v$ Godwin (August 2004), the High Court supported the government's argument that the 1958 Migration Act authorizes indefinite detention of unlawful non-citizens ('aliens'), including those whose asylum application had failed. In other words a stateless person can be held in immigration detention indefinitely, including for life, even if he or she wishes to leave Australia. ${ }^{53}$ Finally, in Re Woolley; Ex parte Applicants M276/2003 (October 2004), the High Court held that the Al-Kateb decision applies to all aliens, whether adults or children,

\footnotetext{
51) Australian Government 2007.

52) Human Rights Watch 2006.

53) This is what happened to Peter Qasim, who was born in the disputed territory of Kashmir, India but fled to Australia as an asylum seeker in 1998 because of fears of political persecution. Qasim arrived in Australia without identity documents and India refused to acknowledge that he was an Indian citizen. As an 'illegal' stateless person, Qasim was placed in mandatory detention where he remained for seven years. In July 2005 he was released and given a 'Return Pending Bridging Visa' which allowed him to remain in Australia temporarily until he could be deported to another country. See BBC News 2005.
} 
therefore "there is no constitutional limitation on the immigration detention of children." ${ }^{44}$ According to then Prime Minister John Howard such sovereign authority is justified inasmuch as "It is in the national interest that we have the power ... to prevent, beyond any argument, people infringing on the sovereignty of this country." 55

A similar system of containment and exclusion has been assembled across Europe and the UK. With regard to 'irregular' migration the European Union has increasingly focused on extraterritorial policing, incarceration, and deportation of asylum-seekers, and hundreds of detention centres have been established in EU states. ${ }^{56}$ The resulting system of containment and exclusion has been referred to as 'Fortress Europe. ${ }^{57}$ In 2003 for instance, the United Kingdom proposed "a radically new approach to delivering the reduction of asylum seeker numbers" based on two types of "zones of protection": "regional protection zones" located outside Europe which would address asylum claims arising from regional conflicts or natural disasters, and "transit processing centres" located along the borders of the European Union which would process asylum claims without asylum-seekers traveling to the countries in which they want to seek asylum. ${ }^{58}$ As with Australia's 'Pacific Solution,' this proposal has a dual effect: first, it incapacitates the ability of asylum-seekers to apply for refugee status since EU states are obligated to investigate asylum claims only when an application is lodged on the territory of a member state; second, it creates a mechanism for lowering the standards for repatriation and facilitates mass deportation by maintaining 'transit' camps outside European borders. According to one report, what is most disturbing about the recent $\mathrm{EU}$ asylum directives is their "abandonment of the principle of non-refoulement" and their "declared and expressed intention to return people from EU states without examining their claim to asylum." 59

Contrary to the stated aim of 'protection' zones, the increased militarization of European border control has increased the desperation, vulnerability, and degradation of refugees. ${ }^{60}$ As Matthew Gibney explains, "While

\footnotetext{
54) Australian Government 2004.

55) Kelly 2001, emphasis added.

56) Marfleet 2006, p. 4 and p. 55.

57) See Geddes 2000 and Milborn 2007.

58) "Home Secretary Statement on Zones of Protection" (27 March 2003), available online at http://www.asylumaid.org.uk/Press\%20statements/home_secretary_statement_on_zone.htm.

59) Schuster 2005, p. 38.

60) Human Rights Watch (2007), for example, reports that more than 900 unaccompanied children from Africa arrived in the Canary Islands by boat in 2006. In response the Spanish
} 
variations remain across countries, in the last decade those seeking refuge have increasingly faced the prospect of detention, denial of the right to work, limitations or exclusions from welfare benefits, diminishing rights to appeal negative decisions, and, ultimately, deportation." For that reason, Gibney adds, "woe betide those who arrive in Western states claiming to be a refugee." ${ }^{\prime 11}$ Recent policies and practices towards the displaced strategically (re)define refugees and stateless persons solely through an exclusionary process which places them outside the community of 'privileged' rights-holders yet within the realm of sovereign power, constituting them as superfluous human beings in a state of permanent limbo - despite the fact that each of the countries mentioned above are signatories to all the major international human rights treaties proclaiming the 'inherent dignity' and 'inalienable rights' of all persons. The strategy of inclusive exclusion serves ultimately to buttress states' denial of responsibility to those outside their borders.

\section{Inclusive Exclusion as Global Apartheid}

This strategy may also be viewed as an attempt to exploit racist and xenophobic tendencies in order to shape perceptions about stateless persons as undesirable 'others' seeking to squander the resources of the state and exploit the good will of the nation, thereby corrupting the health and welfare of the nation-state. In this way the asylum process serves predominantly a police rather than a humanitarian function. This position further enhances the notion that state borders are a 'natural' boundary separating an essentialist and pregiven 'us' from 'them,' whereby sovereignty is premised upon the classification, regulation, restriction and exclusion of asylum-seekers as threatening 'interlopers' and 'problems.' But the paradoxical manner of this exclusion, as Arendt recognized, entails insertion within the interior of sovereign power.

From this perspective the nexus of sovereign power and statelessness can be aptly characterized as a virulent system of global apartheid which

\footnotetext{
government opened four new 'emergency centres,' in which the majority of the children are being detained for indefinite periods and, according to HRW observers, are regularly subjected to abuse and ill-treatment by staff. The children have also been denied the opportunity to apply for asylum, as required by the 1989 Convention on the Rights of the Child (ratified by Spain in 1990).

61) Gibney 2006, p. 141.
} 
establishes a permanent underclass of superfluous human beings. One of the core functions of sovereign power - the creation and coercive enforcement of national identity boundaries - now takes place within a global context where frontiers are dynamically 'managed' in extraterritorial spaces and through deterritorialized forms of rule. Even as the nation-state has been reconfigured in the global age it nevertheless operates so as to draw new lines of demarcation for maintaining segregation between 'insiders' and alien 'outsiders,' thereby perpetuating inequality of rights and social, economic, and political status. According to Anthony Richmond, the current treatment of stateless persons, refugees, and immigrants predominantly from poorer countries closely resembles the apartheid system of South Africa because it systemically discriminates on the basis of birthplace, race, or ethnicity; differentially assigns rights (or denies them altogether) according to the naturalization of identity; employs state authority to militarize borders; forcibly expels people to zones and camps ('homelands') of containment and detention; and justifies coercive exclusion of 'others' in the name of security for a relatively homogeneous population. ${ }^{62}$

Étienne Balibar similarly argues that global apartheid has arrived with the transformation of the international system into a global order which nevertheless retains the nation-state as its core political and administrative unit. Following Arendt's lead, Balibar diagnoses the paradoxes that arise as state power becomes increasingly relayed through global networks. Most fundamentally he suggests, "At the moment at which humankind becomes economically and, to some extent, culturally 'united,' it is violently divided 'biopolitically'." ${ }^{3}$ For Balibar, even the recent processes of European unification reveal contradictions between the universalist ideal of human rights and the practice of (European) citizenship as both a model of cosmopolitan inclusion and a mechanism of exclusion applied to immigrants, refugees, and stateless persons. The main problem is that inclusion remains structurally tied to national identity. On the one hand, the birth of the European Union brought with it the new category of 'European citizens' and the promise of the transnationalization of rights. On the other hand, while the 1991 Maastricht Treaty introduced the legal notion of a common European citizenship, according to the terms of the 1997 Treaty of Amsterdam this citizenship is reserved only to those persons who already possess the nationality of a member state. In this way the EU has further

62) Richmond 1994 , esp. pp. 206-217.
63) Balibar 2004, p. 130. 
entrenched the differentiation of the entire population of Europe into citizens, or the 'European people' proper, and aliens, a class which paradoxically includes "the immigrant population permanently residing in Europe." ${ }^{64}$ In basing the possession of European citizenship rights upon prior national belonging - while institutionally retaining each state's right to determine its sovereign control of nationality criteria at the same time as 'harmonizing' Europe-wide refugee and asylum policies - the EU has constructed a new form of identity and citizenship that preserves rather than overcomes its colonial past.

Parallel to the historical example of apartheid, contemporary Europe includes within its borders tens of thousands of "insiders officially considered outsiders," viewed biopolitically as a minority population whose family compositions, ways of life and so forth must be controlled (or moulded) to protect the 'quality' of the existing dominant national community. The intersection of immigration policy with family politics in conjunction with the creation of European citizenship illustrates the contradictory and evolutionary pattern of "European citizenship-cum-apartheid" as a global-local problem. ${ }^{65}$ For Balibar this institutionalized segregation of the European population not only establishes a permanent underclass in European states and cities but more broadly symbolizes how the globalized world is steadily divided into "life zones and death zones" within cities, states, and regions across the globe. ${ }^{66}$ Whether in Europe or elsewhere in the globalized world, whole classes of people - including refugees, asylum-seekers, and migrant workers - become de facto if not de jure stateless persons as the mutating borders of exclusion continually deprive individuals and communities of the ability to effectively exercise their civil, political, social, and economic rights. The destructive tendency of global apartheid to segregate certain groups of people into "death zones" where human rights have been withdrawn is, Balibar contends, a process which reproduces "populations that are not likely to be productively used or exploited but are always already superfluous, and therefore can be only eliminated either through 'political' or 'natural' means." ${ }^{\text {"67 }}$ As a superfluous population, stateless persons are "neither assimilated and integrated nor immediately eliminated" but forced

64) Balibar 2004, p. 122.
65) Balibar 2004, p. 124.
66) Balibar 2004, p. 126.
67) Balibar 2004, p. 128. 
to remain in institutionalized "limbo" spaces which serve as the preparatory conditions of possibility for their eventual elimination. ${ }^{68}$

The containment, detention, and segregation of stateless persons and refugees as practices of global apartheid calls for recognition of a political principle contained in Arendt's work which is necessarily correlative to the right to have rights: freedom of movement. What is most at stake politically for Arendt with regard to statelessness is that the deprivation of rights which accompanies this condition amounts to the destruction of the agency and dignity of the human person. To be made stateless is to be denied the capacity to act and speak in a polity where others regard one as an equal, and where one's actions and speech can assume a meaningful political presence. One can be the bearer of human rights only when one belongs to, and is claimed by a political community which recognizes one's reciprocal claim upon it. Inasmuch as the stateless are deprived of a political way of life they are deprived "not of the right to freedom, but of the right to action; not of the right to think whatever they please, but of the right to opinion." ${ }^{69}$ This emphasis on agency points towards what I suggest is a vital inner connection between the right to have rights and freedom of movement. According to Arendt freedom of movement is "historically the oldest and also the most elementary" of all human liberties. ${ }^{70}$ In the first instance this is because being able "to depart for where we will is the prototypical gesture of being free," just as "limitation of freedom of movement has from time immemorial been the precondition for enslavement." ${ }^{11}$ But there is a further sense in which freedom of movement is essential to the right to have rights. Arendt stresses that freedom of movement "is also the indispensable condition for action." Further, because "both action and thought occur in the form of movement," it is clear that freedom of movement "underlies both." 72

Hence, as "the indispensable condition for action," the right to have rights cannot be said to be properly guaranteed and exercised without a corresponding guarantee of freedom of movement. It is for this reason that restrictions on freedom of movement serve as one of the unmistakable mechanisms for the production of rightlessness, most egregiously in the

\footnotetext{
68) Balibar 2005, pp. 31-34.

69) Arendt 2004, p. 376.

70) Arendt 1968, p. 9.

71) Arendt 1968, p. 9.

72) Arendt 1968 , p. 9.
} 
case of stateless persons. Similarly, forced displacement, refoulement, rendition, and any repatriation that is not legitimately voluntary - that is, made under conditions where the person "making that choice is currently in possession of his or her civil rights"73 - perpetuate the condition of rightlessness through deprivation of the freedom of movement. All of this can be viewed in light of Arendt's critique of sovereignty. For Arendt, sovereignty represents a mistaken conception of freedom precisely because sovereignty seeks to fix and delimit movement as the form of contingency and spontaneity characteristic of action and speech. Yet action, she says, "always establishes relationships and therefore has an inherent tendency to force open all limitations and cut across all boundaries." ${ }^{.4}$ Conceived as "uncompromising self-sufficiency and mastership," 75 sovereignty responds to the contingency of political action by asserting the absolute dominance of the sovereign will over the realm of human affairs and thus over the freedom of movement of the plurality of individuals and groups inhabiting the earth. Consequently, sovereign power requires a condition of inequality for its very functioning: it must place limits upon freedom of movement and resort to mechanisms of exclusion if it is to assert its supremacy over people and territory. The sovereignty of the modern nation-state is thus placed on a politically disastrous collision course with freedom of movement and the right to have rights. This way of framing the sovereign power to exclude and contain enables us to understand statelessness as nothing less than the categorical unwillingness to share the world with others. ${ }^{76}$

\section{Conclusion}

The importance of Arendt for social and political thinking today is in continuing the critique of the contradictory reliance upon the categories of inherent, inalienable, or natural rights within a global system of sovereign states. The right to have rights is the right to membership in a political community, and its meaning and value can only derive from each person actually experiencing the political form of life proper to human beings. By thinking of human rights in metaphysical terms - as something we possess independently of membership in a political community - we fail to fully

\footnotetext{
73) Stevens 2006, p. 67.

74) Arendt 1958, p. 190.

75) Arendt 1958, p. 234.

76) Arendt 1968, p. 25.
} 
grasp the crisis of human rights exemplified by stateless persons, a crisis that has grown more rather than less acute since the time of Arendt's intervention.

Arendt's attempt to come to grips with the degradation that results from this abject loss of one's place in the common world provoked her critique of sovereignty as the ultimate arbiter and delimiter of movement. I have sought to show that the exclusionary logic of the globalized sovereign state continues to define in advance the existence of a class of human beings who do not belong, because they lack the illusive national, racial, ethnic, or religious identity that supposedly undergirds it. Such people are violently thrown back upon their 'merely human' status. What the conventional approach to the problem of stateless persons misses, then, is the perverse symbiosis that exists between sovereignty and statelessness: statelessness is only insofar as the sovereign power of exclusion overdetermines the world we share with a plurality of others. Arendt's account of rightlessness complicates the usual story. Statelessness is not simply a superstructural humanitarian problem but a recurring form of global apartheid constituted by the state and sovereign power.

Arendt's analysis of human rights, sovereignty, and statelessness relocates the focus of attention back to the political and the necessity of membership. Every stateless person is a rightless nonmember as the result of a state's action, or inaction as the case may be. When a state is faced with a stateless person, when it encounters his or her human aspiration to exercise freedom of movement, it is faced with a clear political choice: to include or to exclude this person. Insofar as the decision is exclusion, then a state is complicit in the perpetuation of rightlessness and the misery of those who are made into the type of superfluous human beings put into internment camps by their 'friends.' In ceasing to belong to any rights-guaranteeing community whatsoever, the stateless person stands in stark contrast to the citizen included in the public sphere. Whereas the latter become fully human in a common world shared with others, the former are alienated from this world and lose their relevance to others; they are, paradoxically, stripped of something fundamental to their human dignity exactly when they are "nothing but human beings." 77 As scholars and human beings, we must take up Arendt's challenge to confront squarely the institutionalized segregation of the international system if we are to find a way beyond the tragedy of mass statelessness.

77) Arendt 2007, p. 273. 


\section{References}

Agamben, Giorgio 1998, Homo Sacer: Sovereign Power and Bare Life, Stanford: Stanford University Press.

Arendt, Hannah 2007, The Jewish Writings, New York: Schocken Books.

Arendt, Hannah 2004, The Origins of Totalitarianism, New York: Schocken Books.

Arendt, Hannah 1994, Essays in Understanding 1930-1954, New York: Schocken Books.

Arendt, Hannah 1993, Between Past and Future, Harmondsworth: Penguin Books.

Arendt, Hannah 1968, Men in Dark Times, San Diego, New York and London: Harcourt Brace.

Arendt, Hannah 1958, The Human Condition, Chicago: University of Chicago Press.

Australian Government, Department of Immigration and Citizenship, 27 June 2007, "Temporary Protection Visa Factsheet," http://www.immi.gov.au/media/fact-sheets/ 64protection.htm (14 October 2007).

Australian Government, Department of Immigration and Citizenship, 2005, "Annual Report, 2004-05," http://www.immi.gov.au/about/reports/annual/2004-05/judicial_decisions. htm (14 October 2007).

Balibar, Étienne 2005, "Difference, Otherness, Exclusion," Parallax, 11, 1: 19-34.

Balibar, Étienne 2004, We, the People of Europe? Reflections on Transnational Citizenship, Princeton and Oxford: Princeton University Press.

Batchelor, Carol A. 1995, "UNHCR and Issues Related to Nationality," Refugee Studies Quarterly, 14, 3: 91-112.

BBC News, 17 July 2005, “Australia Frees 'Indian' Migrant,” http://news.bbc.co.uk/1/hi/ world/south_asia/4690423.stm (15 October 2007).

Benhabib, Seyla 2004, The Rights of Others: Aliens, Residents, and Citizens, Cambridge: Cambridge University Press.

Benhabib, Seyla 2002, "Political Geographies in a Global World: Arendtian Reflections," Social Research, 69, 2: 539-566.

Geddes, Andrew 2000, Immigration and European Integration: Towards Fortress Europe?, Manchester: Manchester University Press.

Gibney, Matthew J. 2006, “A Thousand Little Guantánamos': Western States and Measures to Prevent the Arrival of Refugees," in Kate E. Tunstall (ed.), Displacement, Asylum, Migration: The Oxford Amnesty Lectures 2004, pp. 139-169, Oxford: Oxford University Press.

Howard, Jessica 2003, "To Deter and To Deny: Australia and the Interdiction of Asylum Seekers," Refuge, 21, 4: 35-50.

Human Rights Watch, July 2007, "Unwelcome Responsibilities: Spain's Failure to Protect the Rights of Unaccompanied Migrant Children in the Canary Islands", http://hrw. org/reports/2007/spain0707/spain0707web.pdf (15 October 2007).

Human Rights Watch 2006, "Commentary on Australia’s Temporary Protection Visas for Refugees," http://www.hrw.org/backgrounder/refugees/australia051303.htm (15 October 2007).

Isaac, Jeffrey C. 1998, Democracy in Dark Times, Ithaca and London: Cornell University Press.

Kelly, Fran, 30 August 2001, “Tampa Asylum Seekers Caught in Political Deadlock," Australia Broadcasting Corporation, http://www.abc.net.au/7.30/content/2001/s355371. htm (14 October 2007). 
Marfleet, Philip 2006, Refugees in a Global Era, Basingstoke: Palgrave Macmillan.

Milborn, Corinna, May 2007, "The Assault on Fortress Europe: Thousands are On Their Way, But Europe Doesn't Want Them,” a Goethe-Institut Report, http://www.goethe. de/ges/pok/prj/mig/en2358674.htm (15 October 2007).

Nyers, Peter 2006, Rethinking Refugees: Beyond States of Emergency, New York and London: Routledge.

Oxfam Australia, February 2002, "Adrift in the Pacific: The Implications of Australia's Pacific Refugee Solution," http://www.oxfam.org.au/campaigns/refugees/still_drifting/still_drifting. pdf. (16 October 2007).

Richmond, Anthony H. 1994, Global Apartheid: Refugees, Racism, and the New World Order, Oxford and New York: Oxford University Press.

Schuster, Liza 2005, The Realities of a New Asylum Paradigm. Working Paper No. 20, Centre on Migration Policy and Society, Oxford University, http://www.compas.ox.ac. uk/publications/papers/Liza\%20Schuster\%20wp0520.pdf (16 October 2007).

Stevens, Jacob 2006, "Prisons of the Stateless," New Left Review, 42: 53-67.

Young-Bruehl, Elisabeth 2004, Hannah Arendt: For Love of the World, 2nd edition, New Haven and London: Yale University Press.

UNHCR, June 2007, Global Trends 2006: Refugees, Asylum-seekers, Returnees, Internally Displaced and Stateless Persons, http://www.unhcr.org/statistics/STATISTICS/4676a71d4. pdf. (2 August 2007).

UNHCR, September 2006, "Refugees by Numbers 2006 Edition," http://www.unhcr.org/ basics/BASICS/4523b0bb2.pdf. (2 August 2007).

Weissbrodt, David and Clay Collins 2006, "The Human Rights of Stateless Persons," Human Rights Quarterly, 28: 245-276. 
Copyright of Societies Without Borders is the property of Brill Academic Publishers and its content may not be copied or emailed to multiple sites or posted to a listserv without the copyright holder's express written permission. However, users may print, download, or email articles for individual use. 